\title{
SUBSTRATE SPECIFIC HYDROLYSIS OF AROMATIC AND AROMATIC-ALIPHATIC ESTERS IN ORCHID TISSUE CULTURES ${ }^{\mathrm{X}}$
}

\author{
AGNIESZKA MIRONOWICZ ${ }^{*}$, KRYSTYNA KUKUŁCZANKA**, ANTONI SIEWIŃSKI ${ }^{*}$ \\ ${ }^{*}$ Department of Fundamental Chemistry, Agricultural University of Wroctaw, ul. Norwida 25, 50-375 Wroctaw, Poland \\ ** Botanical Garden, The University of Wroctaw, ul Sienkiewicza 23, 50-335 Wroctaw, Poland
}

(Received: December 20, 1990. Accepted: August 16, 1993)

\begin{abstract}
We found that tissue cultures of higher plants were able, similarly as microorganisms, to transform low-molecular-weight chemical compounds. In tissue cultures of orchids (Cymbidium 'Saint Pierre' and Dendrobium phalaenopsis) acetates of phenols and aromatic-aliphatic alcohols were hydrolyzed, whereas methyl esters of aromatic and aromatic-aliphatic acids did not undergo this reaction. Acetates of racemic aromatic-aliphatic alcohols were hydrolyzed with distinct enantiospecificity.
\end{abstract}

KEY WORDS: Orchidaceae, tissue cultures, aromatic-aliphatic esters, hydrolysis

\section{INTRODUCTION}

We used tissue cultures of orchids (Mironowicz et al. 1987) in our earlier studies on utilization of higher plants for biotransformation. The substrates we transformed belonged to the isoprenoids. We found that the tissue cultures of Cymbidium 'Saint Pierre' and Dendrobium phalaenopsis were able to transform low molecular weight compounds like methyl acetate (we observed hydrolysis of the ester link) whereas higher molecular-weight substrates such as androstane derivatives were transformed in trace amounts only (mutual transformation of carbonylhydroxyl group in tetosterone and androstendione).

In the screening carried out using the same two tissue cultures we also found that they were able to transform aromatic esters, some of which can be considered anologues and derivatives of shikimic acids (Geissman and Crout 1969).

\section{MATERIALS AND METHODS}

The transformations were carried out using tissue cultures of the orchids: Cymbidium 'Saint Pierre' (CSP) and Dendrobium phalaenopsis (D.p.) (clone 303/15) supplied by the laboratory of tissue cultures, Botanical Garden in Wrocław. Fifteen milligrams of the pertinent substrate dissolved in $1 \mathrm{ml}$ of acetone were introduced into $50 \mathrm{ml}$ of two-week-old cultures containing protocorm agglomerates (Mironowicz et al. 1987). The culture with the substrate was shaken for 14 days at $20-24{ }^{\circ} \mathrm{C}$ in an $18 \mathrm{hr}$ photoperiod (2000 1x). The mixture of products was extracted with chloroform $(3 \times 50 \mathrm{ml})$, and analysed by thin layer chromatography (TLC), gas chromatography (GC) and infrared spectrum (IR). Individual compounds were identified by comparing their chromatograms and/or spectra with those obtained from authentic standard or with literature data.

TABLE 1. Specific optical rotations of hydrolysis products and conditions of identification

${ }^{\mathrm{x} /}$ Concentration $(\mathrm{g} / \mathrm{ml})$ in chloroform CSP - Cymbidium 'Saint Pierre' D.p. - Dendrobium phalaenopsis

\begin{tabular}{|c|c|c|c|c|c|c|c|}
\hline \multirow[t]{2}{*}{ Substrate } & \multirow[t]{2}{*}{ Tissue of } & \multicolumn{2}{|c|}{ Alcohol mixture after hydrolysis } & \multicolumn{2}{|c|}{ Unreacted esters } & \multicolumn{2}{|c|}{ Separation conditions } \\
\hline & & 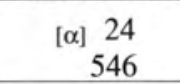 & $c^{1 x}$ & $\begin{array}{r}{[\alpha] 24} \\
546\end{array}$ & $c^{1 x}$ & GC & $\mathrm{CC}$ \\
\hline \multirow[t]{2}{*}{$( \pm) 4$} & CSP & $-16.2^{\circ}$ & 4.2 & $+24.9^{\circ}$ & 18.8 & \multirow{2}{*}{$\begin{array}{c}10 \% \text { DEGA } \\
150^{\circ}\end{array}$} & \multirow{2}{*}{$\begin{array}{c}\text { hexane: } \\
\text { ethyl ether 15:1 }\end{array}$} \\
\hline & D.p. & $-19.5^{\circ}$ & 1.9 & $+8.4^{\circ}$ & 6.9 & & \\
\hline ( \pm ) 5 & $\begin{array}{l}\text { CSP } \\
\text { D.p. }\end{array}$ & $\begin{array}{r}-8.0^{\circ} \\
+4.0^{\circ}\end{array}$ & $\begin{array}{l}1.7 \\
1.0\end{array}$ & $\begin{array}{r}+12.0^{\circ} \\
-1.4^{\circ}\end{array}$ & $\begin{array}{l}5.4 \\
5.6\end{array}$ & $\begin{array}{c}3 \% \text { OV } 17 \\
180^{\circ}\end{array}$ & $\begin{array}{c}\text { hexane: } \\
\text { acetone } 20: 1\end{array}$ \\
\hline$( \pm) 6$ & $\begin{array}{l}\text { CSP } \\
\text { D.p. }\end{array}$ & $\begin{array}{r}-5.4^{\circ} \\
+5.0^{\circ}\end{array}$ & $\begin{array}{l}2.6 \\
1.6\end{array}$ & $\begin{array}{r}+5.0^{\circ} \\
-1.0^{\circ}\end{array}$ & $\begin{array}{r}10.7 \\
9.6\end{array}$ & $\begin{array}{c}3 \% \text { OV } 17 \\
180^{\circ}\end{array}$ & $\begin{array}{c}\text { hexane: } \\
\text { ethyl ether 10:1 }\end{array}$ \\
\hline$( \pm) 7$ & CSP and D.p. & $0^{\circ}$ & & $0^{\circ}$ & & $\begin{array}{c}3 \% \text { OV } 17 \\
130^{\circ}\end{array}$ & - \\
\hline
\end{tabular}

x Part 28 of the series "Biotransformations". Part 27: see Draczyńska-Łusiak 1989.

Offprint requests to: Antoni Siewiński 
The procedure was carried out 4-6 times for all of the substrates (1-16). The specific optical rotations of the transformation products, as well as the column and gas chromatography parameters are presented in Table 1 . In this table the values of specific optical rotations $(\alpha)$ are given only for a single transformation in which the products showed the highest $\alpha$ values.

The results of transformations (degree of hydrolysis) of products 1-7 and 12-15 are presented as average values calculated for several repetitions (Table 2).

The transformations were carried out by the tissue cultures of Cymbidium 'Saint Pierre' and Dendrobium phalaenopsis under previously described conditions (Mironowicz et al. 1987). The substrates used for transformation are esters of simple and multisubstituted phenols, aromatic-aliphatic alcohols and acids (Fig. 1.).

They contained two types of ester links:

- acetates of phenols and aromatic-aliphatic alkohols as in phenyl acetate (1), benzyl acetate (2), cinnamonyl acetate (3), $( \pm) 1$-phenyl-ethyl acetate $[( \pm) 4],( \pm) 1-(1$-naphtyl)-ethyl acetate $[( \pm) 5],( \pm) 1-(2$-naphtyl)-ethyl acetate $[( \pm) 6]$ and $( \pm) 2$-phenyl-butyl acetate $[( \pm) 7]$;

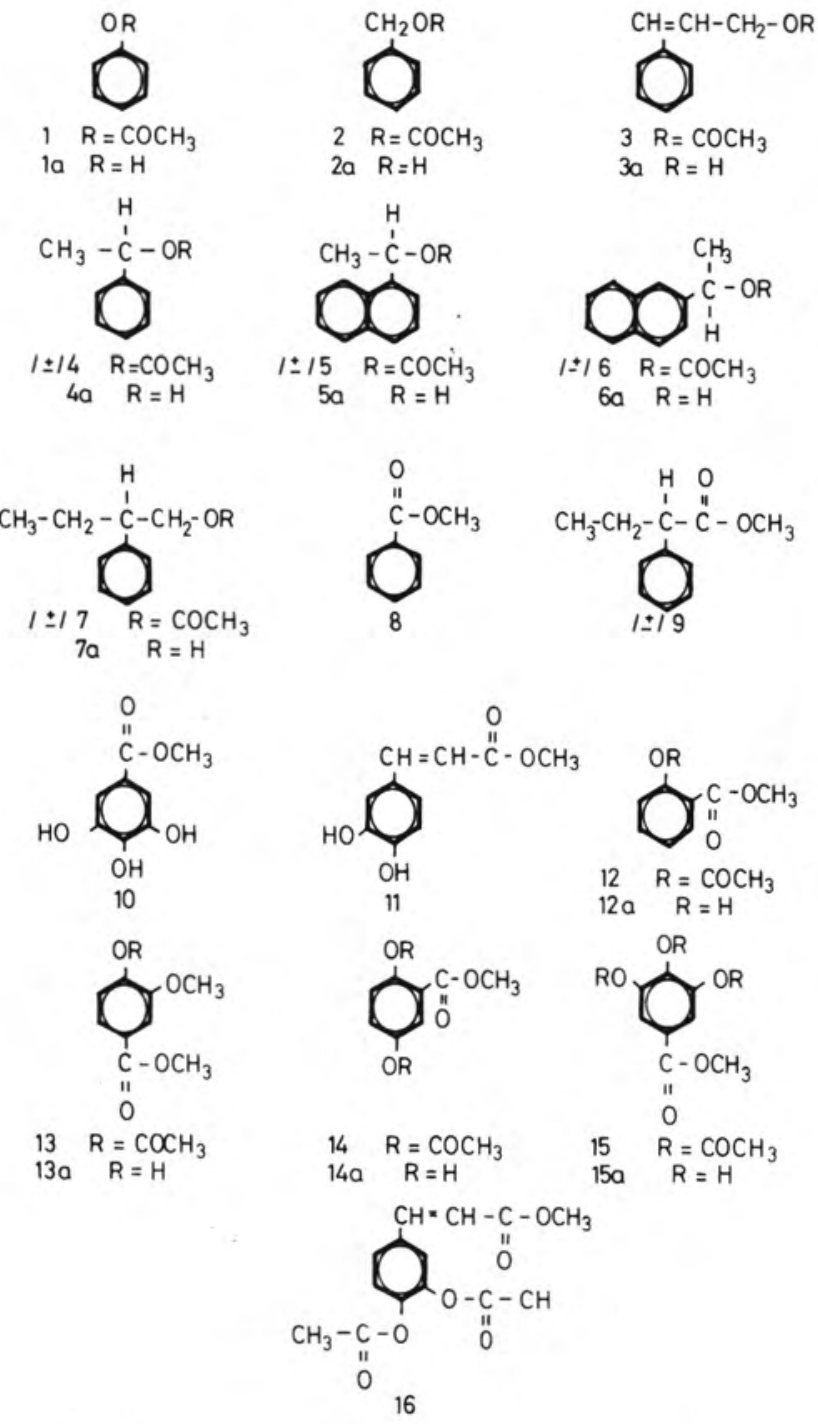

Fig. 1. Substrates (1 to 16) used for hydrolysis and alcohols (1a to 7a, 12a and 15a) obtained therefrom by tissue cultures of Cymbidium 'Saint Pierre' and Dendrobium phalaenopsis.
- methyl esters of aromatic-aliphatic acids as in methyl benzoate $(8),( \pm)$ methyl -2-phenyl butyrate $[( \pm) 9]$, methyl gallate (10) and methyl caffeate (11);

- both of these links were present in methyl-acetoxy salicylate (12), methyl-acetoxy vanillate (13), methyl-2,5-diacetoxy benzoate (14), methyl-triacetoxy gallate (15) and methyldiacetoxy caffeate (16).

The mixtures of the products were analyzed by thin-layer and gas chromatography or spectroscopically after isolation of individual compounds.

\section{RESULTS AND DISCUSSION}

The only reaction observed in both tissue cultures was the hydrolysis of acetate groups in the simple substrates 1 to 7 and in multisubstituted substrates such as 12, 13, 14, and 15 .

However, there was one exception: methyl diacetoxy caffeate (16) appeared resistant to this reaction.

TABLE 2. Hydrolysis of acetate groups into simple multisubstituted aromatic substrates in tissue cultures of Cymbidium 'Saint Pierre' and Dendrobium phalaenopsis (D.p.)

\begin{tabular}{|c|c|c|c|}
\hline \multirow[t]{2}{*}{ Substrates } & \multirow[t]{2}{*}{ Products } & \multicolumn{2}{|c|}{$\begin{array}{c}\text { Degree of } \\
\text { hydrolysis } \\
(\%)^{x}\end{array}$} \\
\hline & & CSP & D.p. \\
\hline $\begin{array}{l}\text { phenyl acetate (1) } \\
\text { benzyl acetete (2) }\end{array}$ & $\begin{array}{l}\text { phenol (1a) } \\
\text { benzyl alcohol }(2 a) \\
\text { and } 2\end{array}$ & $\begin{array}{r}100 \\
68\end{array}$ & $\begin{array}{r}100 \\
66\end{array}$ \\
\hline $\begin{array}{l}\text { cinnamonyl acetate }(3) \\
\qquad( \pm)-1-\text { phenyl-ethyl } \\
\text { acetate }(( \pm) 4 \text { xx }\end{array}$ & $\begin{array}{l}\text { cinnamonyl alcohol (3a) } \\
\text { and } 3 \\
1 \text {-phenyl ethanol ( } 4 a) \text {, } \\
4 \text { and acetophenone (4b) }\end{array}$ & $\begin{array}{l}28 \\
43\end{array}$ & $\begin{array}{l}12 \\
23\end{array}$ \\
\hline $\begin{array}{l}( \pm)-1-(1-\text { naphtyl })- \\
\text { ethyl acetate }(( \pm) 5)\end{array}$ & $\begin{array}{l}\text { 1-(1-naphtyl)-ethanol } \\
\text { (5a) and } 5\end{array}$ & 26 & 16 \\
\hline $\begin{array}{l}\quad \pm) \text {-1-(2-naphtyl)- } \\
\text { ethyl acetate }((+) 6)\end{array}$ & $\begin{array}{l}\text { 1-(2-naphtyl)-ethanol } \\
\text { (6a) and } 6\end{array}$ & 27 & 10 \\
\hline $\begin{array}{l}( \pm) \text {-2-phenyl-butyl } \\
\text { acetate }(( \pm) 7)\end{array}$ & $\begin{array}{l}\text { 2-phenyl butanol (7a) } \\
\text { and } 7\end{array}$ & 46 & 20 \\
\hline $\begin{array}{l}\text { methyl-acetoxy salicylate } \\
(12)\end{array}$ & $\begin{array}{l}\text { methylsalicylate (12a) } \\
\text { and } 12\end{array}$ & 100 & 92 \\
\hline $\begin{array}{l}\text { methyl-acetoxy vanilate } \\
\text { (13) }\end{array}$ & $\begin{array}{l}\text { methyl vanillate (13a) } \\
\text { and } 13\end{array}$ & 100 & 95 \\
\hline $\begin{array}{l}\text { methyl } 2,5 \text {-diacetoxy } \\
\text { benzoate (14) }\end{array}$ & $\begin{array}{l}\text { methyl 2,5-dihydroxy } \\
\text { benzoate (14a) and } 14\end{array}$ & 85 & 95 \\
\hline $\begin{array}{l}\text { methyl-triacetoxy } \\
\text { gallate (15) }\end{array}$ & $\begin{array}{l}\text { methyl gallate (15a) } \\
\text { and } 15\end{array}$ & 35 & 35 \\
\hline
\end{tabular}

${ }^{x}$ Degree of hydrolysis was estimated after the same time (14 days) of transformation in all of the experiments.

${ }^{x x}$ Enantiospecificity of hydrolysis of substrates $( \pm) 4,( \pm) 5,( \pm) 6$ and $( \pm) 7$ was analysed and the results are presented in Table 3.

Methyl. esters in simple, 8 to 11 and multisubstituted substrates, 12 to 16 were found not to undergo any transformation.

Table 2 presents the degree of hydrolysis of acetoxy groups in simple and multisubstituted substrates. 
After 14 days both tissue cultures totally (or almost totally) hydrolyzed acetoxy groups into phenyl acetate (1) and into its simple derivatives: methyl-acetoxy salicylate (12) and methyl -2, 5-diacetoxy benzoate (14).

The products of hydrolysis, i.e. phenols and aromatic-aliphatic alcohols (1a, 2a, 3a, 5a, 6a, 7a, 12a, 13a, 14a and 15a), were stable in the same tissue cultures. Only about $2 \%$ of 1 phenyl-ethanol (4a) was oxidized to acetophenone (4b).

Some of the substrates which underwent the transformation were racemic: $( \pm) 4,( \pm) 5,( \pm) 6$ and $( \pm) 7$. The two-week period did not bring hydrolysis to completion. That is why it was possible to isolate and measure the optical activity of not only the products, but of the remainder of the unreacted substrates as well. Both tissue cultures hydrolyzed the first three substrates enantiospecifically. Cymbidium 'Saint Pierre' hydrolyzed the S esters [(+) (S)4, (-) (S)5 and (-) (S)6] faster than their enantiomers. Dendrobium phalaenopsis transformed the same three substrates not as homogeneously: alcohol (-) (S)4a was formed faster than its enantiomer, but in the two next transformations the enantiomers (-) (R)5 and (-) (R)6 were formed in a small excess.

The fourth of the racemic substrates, ester $( \pm) 7$ was hydrolyzed without enantiospecificity in both cultures; racemic alcohol 7a was found.

TABLE 3. Enantiospecific hydrolysis of acetates of aromatic-aliphatic alcohols by Cymbidium 'Saint Pierre' (CSP) and Dendrobium phalaenopsis (D.p.)

\begin{tabular}{|c|c|c|c|c|}
\hline \multirow{3}{*}{ Substrates } & \multicolumn{4}{|c|}{ Transformation products ${ }^{\mathrm{x}}$} \\
\hline & \multicolumn{2}{|c|}{ In CSP } & \multicolumn{2}{|c|}{ In D.p. } \\
\hline & $\begin{array}{l}\text { Optically } \\
\text { active } \\
\text { alcohols }\end{array}$ & $\begin{array}{l}\text { Unreactetd } \\
\text { substrates }\end{array}$ & $\begin{array}{l}\text { Optically } \\
\text { active } \\
\text { alcohols }\end{array}$ & $\begin{array}{l}\text { Unreacted } \\
\text { substrates }\end{array}$ \\
\hline ( \pm ) 4 & $\begin{array}{c}\text { excess of: } \\
(-) 4 a \\
S: R=66: 34\end{array}$ & $(+) 4$ & $\begin{array}{c}\text { excess of: } \\
(-) 4 a * * \\
S: R=69: 31\end{array}$ & (+) 4 \\
\hline$( \pm) 5$ & $\begin{array}{c}(-) 5 a \\
S: R=55: 45\end{array}$ & (+) 5 & $\begin{array}{c}(+) 5 a \\
S: R=47: 53\end{array}$ & $(-) 5$ \\
\hline$( \pm) 6$ & $\begin{array}{c}(-) 6 a \\
S: R=57: 43\end{array}$ & $(+) 6$ & $\begin{array}{c}(+) 6 a \\
S: R=43: 67\end{array}$ & (-) 6 \\
\hline \multirow[t]{2}{*}{$( \pm) 7$} & $( \pm) 7 \mathrm{a}$ & $(+) 7$ & $( \pm) 7 \mathrm{a}$ & $( \pm) 7$ \\
\hline & \multicolumn{4}{|c|}{ lack of enantiospecificity } \\
\hline
\end{tabular}

${ }^{\mathrm{x}}$ For time of transformation and deegre of hydrolysis of substrates see Table 2.

${ }^{x x}$ Alcohol 4a was further oxidized to acetophenone $\mathrm{C}_{6} \mathrm{H}_{5} \mathrm{COCH}_{3}$ (4b). Degree of oxidation did not exceed $2 \%$ with respect to initial concentration $( \pm) 7$.
The reason for the lack of enantiospecificity, discovered in the hydrolysis of $( \pm) 7$, may be explained by the ester link in it not being bound to the asymmetric carbon atom directly, as could be observed in the first three substrates $( \pm) 4,( \pm) 5$ and ( \pm )6 (see Fig.1).

The discussed enantiospecificity was found by us before in the hydrolysis of the same racemic esters, which were transformed in the culture of a whole intact aquatic plant - Spirodela oligorrhiza (duckweed). All of them were hydrolyzed to S alcohols (Pawłowicz and Siewiński 1987).

Almost all of the substrates used for our purposes were secondary metabolites of higher plants or were similar to their analogues (Geissman et al. 1969, Lüning 1974).

The enantiospecificity of hydrolysis of the racemic substrates in orchid tissue cultures shown above appeared to depend on the species of the higher plant and might supply some information for use in their chemotaxonomy.

The ability of orchid tissue cultures to hydrolyze ester bonds with substrate specificity (only acetoxy groups were hydrolyzed whereas methyl esters remained stable in the same conditions), seems to be similar to the processes carried out by microorgasnisms (Alferman and Reinhard 1980, Berlin 1984).

\section{ACKNOWLEDGMENT}

This work was sponsored by the Polish Academy of Sciences (grant CPBR 3.13).

\section{LITERATURE CITED}

ALFERMAN A.W., REINHARD E., 1980. Biotransformation by plant tissue cultures. Bull. Soc. Chim. France 1-2: II 35

BERLIN J., 1984. Plant cultures - a future source of natural products? Endeavour, New Series 8: 5-8

DRACZYŃSKA-ŁUSIAK B., SIEWIŃSKI A., 1989. Enantioselectivity of the Metabolism of some Monoterpenic Components of Coniferous Tree Resin by Armillariella mellea (Honey Fungus). J. Basic Microbiol. 29(5): 269

GEISMAN T.A., CROUT D.H.F., 1969. Compounds derived from shikimic acid. In: Organic chemistry of secondary plant metabolism. Freeman, Cooper and Company, California: 136

LÜNING B., 1974. Alkaloids in the Orchidaceae. In: The Orchids, Winter C L ed: 349

MIRONOWICZ A., KUKUŁCZANKA K., KRASIŃSKI K., SIEWIŃSKI A. 1987. Transformation of Isoprenoids by Orchids in Tissue Cultures. Phytochemistry 26(7): 1959

PAWŁOWICZ P., SIEWIŃSKI A., 1987. Enantioselective Hydrolysis of Esters and the Oxidation of Aromatic-Aliphatic Alcohols Obtained Therefrom by Spirodela oligorrhiza. Phytochemistry 26(4): 1001

\section{SUBSTRATOWO SPECYFICZNA HYDROLIZA ESTRÓW AROMATYCZNYCH I AROMATYCZNO-ALIFATYCZNYCH ZACHODZĄCA W KULTURACH TKANKOWYCH STORCZYKÓW.}

\section{STRESZCZENIE}

Stwierdzono, że kultury tkankowe roślin wyższych posiadają, tak jak mikroorganizmy, zdolność do transformowania związków chemicznych. W kulturach tkankowych storczyków (Cymbidium 'Saint Pierre' i Dendrobium phalaenopsis) zachodzi hydroliza octanów fenoli i aromatyczno-alifatycznych alkoholi, podczas gdy estry metylowe kwasów aromatycznych i aromatyczno-alifatycznych nie podlegają tej reakcji. Octany racemicznych alkoholi aromatyczno-alifatycznych są hydrolizowane z wyraźną enancjospecyficznością. 